\title{
Siremis: Sistem Informasi Rekam Medis Puskesmas Kecamatan Matraman Jakarta
}

\author{
Siremis: Information System Medical Records at the Community Health Center in \\ Matraman District, Jakarta
}

\author{
Diterima: \\ 22 November 2018 \\ Revisi: \\ 20 Februari 2019 \\ Terbit Online: \\ 18 April 2019
}

\author{
${ }^{1}$ Lydia Salvina Helling, ${ }^{2}$ Endang Wahyudi, ${ }^{3}$ Hasanudin \\ 1,2,3 Sistem Informasi Akuntansi, Universitas Bina Sarana \\ Informatika \\ ${ }^{1,2}$ Jakarta, Indonesia, ${ }^{3}$ Bogor,Indonesia \\ E-mail: ${ }^{1}$ lydia.lsh@bsi.ac.id, ${ }^{2}$ ew4hyudi@yahoo.co.id, ${ }^{3}$ \\ hasanudin.hnu@bsi.ac.id
}

\begin{abstract}
Abstrak - Puskesmas Kecamatan Matraman yang didirikan oleh pemerintah DKI Jakarta pada tanggal 3 Juli tahun 1977 adalah salah satu puskesmas yang selalu melakukan pencatatan dan pencarian data pasiennya pada Rekam Medis. Terselipnya Buku Rekam Medis dan penyusunan yang kurang baik mengakibatkan pencarian data memakan waktu yang agak lama. Hal ini kemudian menjadi faktor dibutuhkannya suatu Sistem Informasi Rekam Medis agar pencatatan riwayat kesehatan pasien dapat tersimpan dan tersusun dalam suatu mekanisme yang baik. Pengembangan sistem pendataan pasien pada Rekam Medis menggunakan metode Waterfall dalam pengembangan perangkat lunaknya. Sedangkan proses pengumpulan data dengan melakukan wawancara kepada bagian yang terkait. Penggambaran dari sistem yang berjalan dapat terlihat dalam bentuk Activity Diagram dan sistem usulan dapat dilihat pada Use Case Diagram, ERD serta LRS nya. Penelitian menghasilkan Sistem Informasi Rekam Medis yang membantu bagian yang terkait dalam mencatat dan mencari data pasien yang dibutuhkan secara cepat dan tepat sehingga tindakan medis dapat segera dilakukan.
\end{abstract}

Kata Kunci- Puskesmas, Rekam Medis, Sistem Informasi, Waterfall

Abstract - The Matraman Sub-district Health Center, which was established on July 3, 1977 in DKI Jakarta, is one of the puskesmas that always records and searches its patient data in Medical Records. This Puskesmas requires a Medical Record Information System so that the recording of the patient's medical history can be stored and arranged in a good mechanism. The development of the patient data collection system in Medical Records uses the Waterfall method in developing the software. While the process of collecting data by conducting interviews with the relevant parts. Depictions of the running system can be seen in the form of Activity Diagrams and proposed systems can be seen in the Use Case Diagram, ERD and LRS. Research produces a Medical Record Information System that helps related parts in recording and searching for patient data needed quickly and precisely so that medical action can be done immediately.

Keywords - Puskesmas, Medical Records, Information Systems, Waterfall. 


\section{PENDAHULUAN}

Kesehatan adalah salah satu faktor penting yang harus selalu diperhatikan oleh manusia dalam mendukung segala aktifitas yang akan dilakukannya. Fasilitas pelayanan kesehatan masyarakat dalam hal ini sangat dibutuhkan untuk membantu masyarakat dalam mengobati segala macam jenis penyakit. Rumah sakit, Poliklinik, Puskesmas, Polindes ( Poliklinik Desa ), dan Pustu ( Puskesmas Pembantu ) merupakan pusat pelayanan kesehatan yang disediakan oleh pemerintah. Puskesmas sebagai Unit Pelaksana Teknis Dinas (UPTD) Kesehatan menjadi ujung tombak dari pelayanan kesehatan di Indonesia. World Health Organization ( WHO ) bahkan merekomendasikan pemanfaatan pelayanan kesehatan merupakan faktor penting dalam penentu kesehatan, yang memiliki relevansi khusus sebagai masalah kesehatan dan pembangunan masyarakat di negara-negara berpenghasilan rendah [1].

Puskesmas Kecamatan Matraman adalah salah satu puskesmas yang selalu berusaha memberikan pelayanan terbaik bagi pasiennya. Pelayanan yang diberikan oleh para petugas medis, mencakup kecakapan, ketepatan dan kesigapan, salah satunya dalam proses mencari data pasien, menjadi tujuan dalam menangani pasien secara baik dan cepat [2]. Semakin banyaknya masyarakat yang berobat ke puskesmas ini berdampak pada tempat penyimpanan data pasien, terutama Buku Rekam Medis yang membutuhkan ruang yang memadai. Hal ini pernah menjadi permasalahan di Rumah Sakit TK.IV dr.Bratanata, Jambi [3]. Buku Rekam Medis yang ditempatkan pada suatu tempat penyimpanan fisik membutuhkan waktu ekstra dalam proses pencariannya. Kerapihan dan terorganisirnya penyimpanan buku Rekam Medis menjadi faktor cepat atau lambatnya mendapatkan buku tersebut, tetapi para petugas medis masih banyak yang kurang disiplin dalam hal ini sehingga pelayanan terhadap pasien agak terhambat[4][5][6]. Hal ini pula yang pernah dibahas pada artikel berjudul "Analisa dan Perancangan Sistem Informasi Rekam Medis Pada Puskesmas Kecamatan X" oleh Niky Hardinata dan Muamar Hi.Muhammad.Sedangkan kualitas pelayanan menjadi salah satu penilaian terhadap fasilitas kesehatan yang diberikan disamping kesembuhan yang didapatkan oleh seorang pasien [2][7].

Isi Rekam Medis meliputi identitas, anamnesa,penentuan fisik, laboratorium, diagnosa segala pelayanan dan tindakan medik yang diberikan kepada pasien, baik yang dirawat inap, rawat jalan maupun pelayanan gawat darurat. Rekam Medis mempunyai pengertian yang sangat luas, tidak hanya tentang kegiatan pencatatan, akan tetapi sebagai suatu sistem penyelenggaraan yang dimulai dari pencatatan pelayanan medik dari pasien, dilanjutkan dengan penanganan berkas dari rekam medis tersebut yang meliputi penyimpanan serta pengeluaran berkas dari tempat penyimpanan untuk melayani permintaan / peminjaman apabila pasien membutuhkannya [5][8]. 
INTENSIF, Vol.3 No.2 August 2019

ISSN: 2580-409X (Print) / 2549-6824 (Online)

DOI: https://doi.org/10.29407/intensif.v3i2.12597

Permasalahan tentang besarnya tempat penyimpanan data pasien dan proses pencarian data yang memerlukan waktu agak lama menjadi bahan pertimbangan dibuatnya Sistem Informasi Rekam Medis ( SIReMis ) oleh penulis.

\section{METODE PENELITIAN}

Puskesmas kecamatan Matraman yang didirikan oleh pemerintah DKI Jakarta pada tanggal 3 Juli tahun 1977, bertempat di daerah matraman, jl kebon kelapa no.29 kelurahan utan kayu selatan. Pada waktu pertama kali didirikan, puskesmas tersebut hanya memiliki satu lantai dengan beberapa poli kesehatan. Seiring berjalannya waktu, renovasi dilakukan terhadap gedung puskesmas tersebut dengan menambahkan lantai pada tanggal 01 juni 1984. Tahun 2015, Puskesmas Kecamatan Matraman berpindah lokasi dikarenakan alih fungsi untuk pembangunan rumah sakit umum daerah tipe D. Saat ini Puskesmas Kecamatan Matraman bertempat di jalan pisangan baru timur no.2A Rt.004 Rw.009 kelurahan pisangan baru Penulis menggunakan beberapa metode pengumpulan data sebagai berikut:

\section{Observasi (Observation)}

Metode pengumpulan data dengan melakukan pengamatan langsung kegiatan pengolahan data dalam peminjaman dan pengembalian buku status RM (Rekam Medis) Puskesmas Kecamatan Matraman

\section{Wawancara (Interview)}

Metode ini dilakukan dengan proses tanya jawab dengan bapak Budi Hartanto selaku bagian penanggung jawab pelayanan RM (Rekam Medis) guna untuk mendapatkan informasi yang tepat dan sesuai kebutuhan.

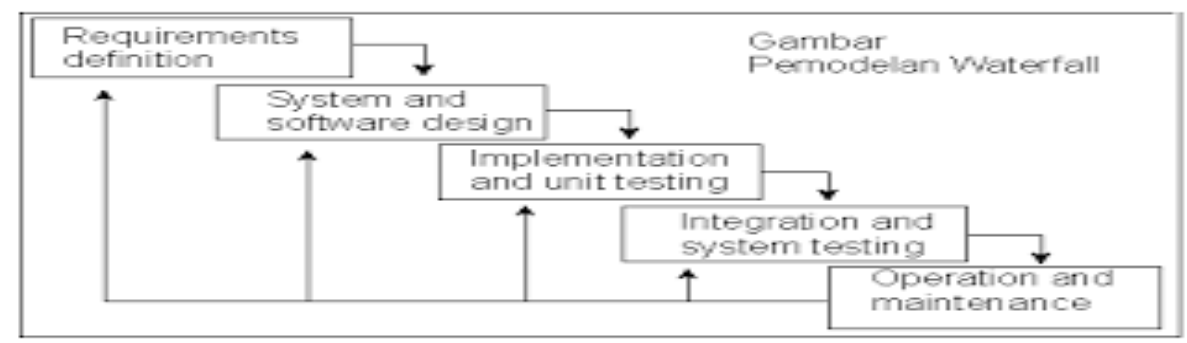

Gambar 1. SiKLus HiduP ( LIFE CYCLE ) DENGAN METODE WATERFALL

Sedangkan untuk pengembangan perangkat lunak, metode yang digunakan adalah metode

Waterfall, yang terbagi menjadi 5 tahap ( gambar 1), yaitu [9][10]:

1. Penentuan dan analisa spesifikasi

Sistem Rekam Medis untuk pasien yang sedang berjalan sekarang masih bersifat manual atau konvesional sehingga untuk pencarian data pasiennya masih mengalami kesulitan karena belum 
tersusun dengan baik. Penulis akan membuat suatu sistem informasi pendataan pasien dalam Rekam Medis sehingga data dapat ditemukan dengan cepat dan terorganisir baik. Penggambaran dari sistem yang berjalan terlihat dalam bentuk diagram aktifitas ( Activity Diagram ). Gambar 2 memperlihatkan simbol - simbol yang dipergunakan dalam diagram aktifitas.

\begin{tabular}{|c|c|}
\hline Simbol & Deslkripsi \\
\hline status awal & $\begin{array}{l}\text { status awal aktivitas sistem. } \\
\text { sebuah aktivitas } \\
\text { memiliki sebuah status awal }\end{array}$ \\
\hline aktivicas & $\begin{array}{l}\text { aktivitas yang dilakukan sistem, } \\
\text { aktivitas biasanya diawali dengan } \\
\text { kata kerja }\end{array}$ \\
\hline percabangan, decision & $\begin{array}{l}\text { asosiasi percabangan dimana jika } \\
\text { ada pilihan aktivitas lebih dari } \\
\text { satu }\end{array}$ \\
\hline penggabungan / join & $\begin{array}{l}\text { asosiasi penggabungan dimana } \\
\text { lebih dari satu aktivicas } \\
\text { digabungkan menjadi satu }\end{array}$ \\
\hline status akhir & $\begin{array}{l}\text { status akhir yang dilakukan } \\
\text { sistem, sebuah diagram aktivitas } \\
\text { memiliki sebuah status akhir }\end{array}$ \\
\hline swimlane & $\begin{array}{l}\text { memisahkan organisasi bismis } \\
\text { yang bertanggung } \\
\text { cerhadap aktivitas yang terjadi }\end{array}$ \\
\hline fork. & $\begin{array}{l}\text { digunakan lik menunjukkan } \\
\text { kegiatan yg dilakukan secara } \\
\text { paralel }\end{array}$ \\
\hline join. & $\begin{array}{l}\text { digunakan utk menunjukkan } \\
\text { kegiatan yg digabungkan }\end{array}$ \\
\hline
\end{tabular}

Gambar 2. SIMBOL DIAGRAM AKTIFITAS

Diagram aktifitas adalah menggambarkan berbagai alir aktifitas dalam sistem yang sedang dirancang, bagaimana setiap alir berawal, dan bagaimana suatu aktifitas berakhir. Activity Diagram juga dapat menggambarkan proses paralel yang mungkin terjadi pada beberapa kegiatan. Sebuah aktifitas dapat direalisasikan oleh satu use case atau lebih. Aktifitas menggambarkan proses yang berjalan, sedangkan use case menggambarkan bagaimana actor menggunakan sistem untuk melakukan aktifitas [9].

2. Disain Sistem Perangkat Lunak

Atas dasar dari analisa terhadap sistem yang berjalan, kemudian akan dibuatkan rancangan sistem usulan berdasarkan kebutuhan yang memang diperlukan untuk suatu sistem informasi pendataan Rekam Medis Pasien. Perancangan database akan menghasilkan beberapa tabel, seperti tabel pasien, tabel Rekam Medis, dan tabel poliklinik. Perancangan antarmuka juga akan menghasilkan beberapa form input, seperti form pendaftaran, form data dokter, dan form tindakan. Sedangkan untuk laporan - laporan yang bisa dihasilkan dengan periode tertentu, seperti laporan kedatangan pasien, laporan dokter per poliklinik, dan laporan pasien per poliklinik.Penggambaran dari sistem usulan akan tersajikan dalam suatu diagram use case ( Use Case Diagram ) dan ERD. 
INTENSIF, Vol.3 No.2 August 2019

ISSN: 2580-409X (Print) / 2549-6824 (Online)

DOI: https://doi.org/10.29407/intensif.v3i2.12597

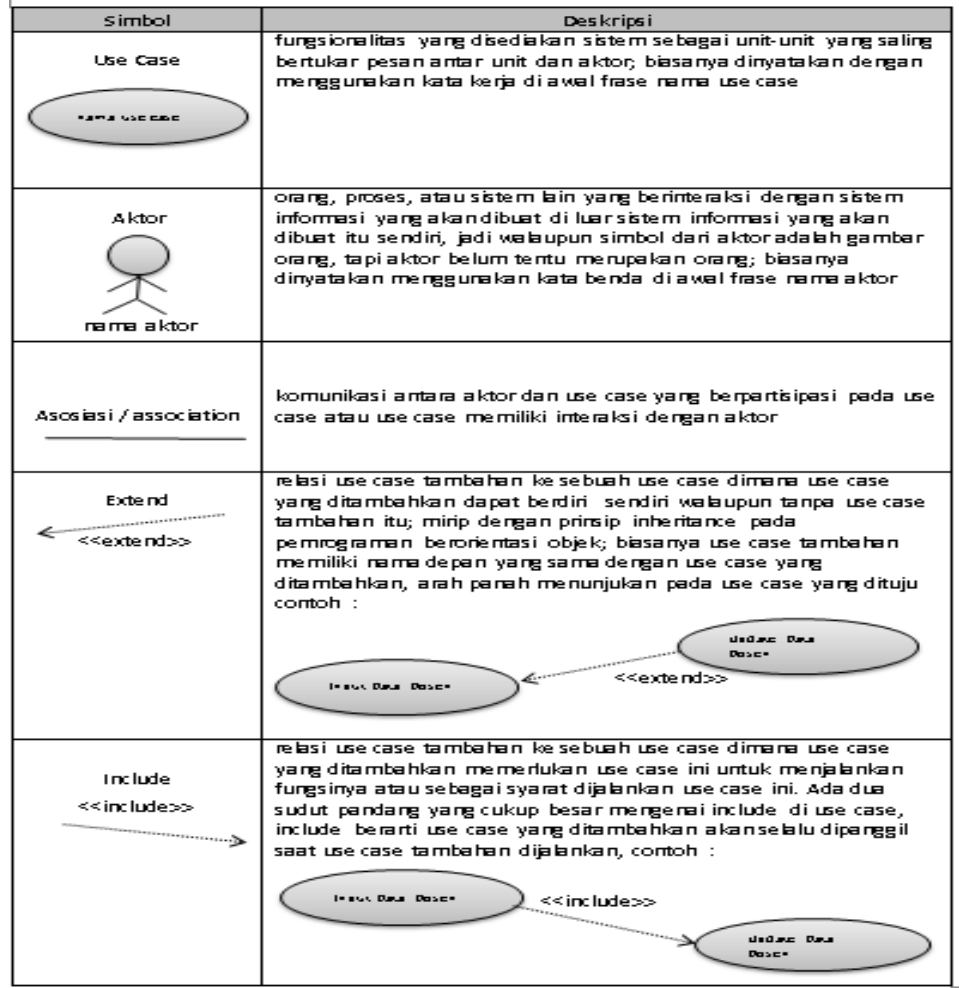

Gambar 3. SIMBOL DIAGRAM USE CASE

Gambar 3 memperlihatkan simbol - simbol yang dipergunakan dalam use case diagram.Use Case Diagram menunjukkan fungsionalitas suatu sistem atau kelas dan bagaimana sistem ini berinteraksi dengan dunia luar, serta dapat dipergunakan untuk memperoleh kebutuhan sistem dan memahami bagaimana sistem seharusnya bekerja [11] . Hal yang ditekankan pada diagram ini adalah "apa" yang diperbuat sistem dan bukan " bagaimana" sistem bekerja [12].Untuk mendeskripsikan use case, kita dapat menjabarkannya dalam skenario. Skenario adalah rangkaian langkah-langkah yang menjabarkan sebuah interaksi antara seorang pengguna dengan sebuah sistem .Use Case Diagram memiliki beberapa tingkatan. Use Case Diagram tingkatan Sea Level khususnya mewakili sebuah interaksi diskrit antara aktor utama dengan sistem. Use Case Diagram tingkatan Fish Level adalah use case yang ada di tingkatan Sea Level yang diberi masukkan ( lebih detil ). Sedangkan Use Case Diagram tingkatan Kite Level adalah Use Case tingkatan Sea Level yang sesuai dengan interaksi bisnis lebih luas. Use Case Kite level biasanya merupakan Use Case bisnis, sedangkan Use Case Sea dan Fish Level merupakan Use Case Sistem [13]. Penggambaran relasi antar data bisa disajikan dalam ERD dan LRS. 


\begin{tabular}{|c|c|}
\hline \multirow[t]{2}{*}{ SIMIBOL } & KETERANGAN \\
\hline & $\begin{array}{l}\text { Entity. Simbol yang menyatakan himpunan entitas ini } \\
\text { bisa berupa suatu elemen lingkungan, sumber daya, } \\
\text { atau transaksi, yang begitu pentingnya bagi perusahaan } \\
\text { sehingga didokumentasikan dengan data. }\end{array}$ \\
\hline & 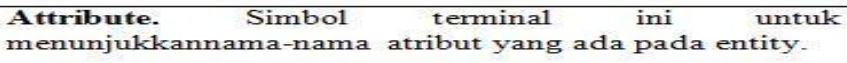 \\
\hline & $\begin{array}{l}\text { Primary Key Attribute. Simbol atribut yang } \\
\text { digarisbawahi, berfungsi sebagai key (kunci) di antara } \\
\text { nama-nama atribut yang ada pada suatu entiti. }\end{array}$ \\
\hline & $\begin{array}{l}\text { Relationship. Simbol ini menyatakan relasi ini } \\
\text { digunakan untuk menunjukkan hubungan yang ada } \\
\text { antara entiti yang satu dengan entiti yang lainnya. }\end{array}$ \\
\hline & $\begin{array}{l}\text { Link. Simbol berupa garis ini digunakan sebagai } \\
\text { penghubung antara himpunan relasi dengan himpunan } \\
\text { entitas dan himpunan entitas dengan atributnya. }\end{array}$ \\
\hline
\end{tabular}

Gambar 4. SIMBOL ERD

Gambar 4 memperlihatkan simbol - simbol yang dipergunakan dalam ERD. ERD ( Entity Relationship Diagram ) dikembangkan berdasarkan teori himpunan dalam bidang matematika dan digunakan untuk pemodelan basis data relasional [14]. Sedangkan LRS ( Logical Record Structured ) dibentuk dengan nomor dari tipe record. Beberapa tipe record digambarkan oleh kotak persegi panjang dan dengan nama yang unik. Perbedaan antara LRS dan ERD adalah nama tipe record berada diluar kotak field tipe record ditempatkan. LRS terdiri dari link-link diantara tipe record. Link ini menunjukkan arah dari satu tipe record lainnya. Banyak link dari LRS yang diberi tanda field - field yang kelihatan pada kedua linktipe record.[15] Penggambaran LRS mulai dengan menggunakan model yang dimengerti. Dua metode yang dapat digunakan, dimulai dengan hubungan kedua model yang dapat dikonversikan ke LRS. Metode yang lain dimulai dengan Entity Relationship Diagram dan langsung dikonversikan ke LRS [16].

\section{Implementasi dan Uji Coba Unit}

Pengujian unit dapat dilakukan dengan melakukan input pada form - form yang terbentuk dengan mempergunakan data nyata yang ada pada sistem sebelumnya. Pengujian terfokus pada perangkat lunak secara logika dan fungsionalitas serta memastikan bahwa semua bagian sudah diuji . Pengujian ini mempergunakan Black-Box Testing yang berfokus pada spesifikasi fungsional dari perangkat lunak. Black-Box Testing bekerja dengan mengabaikan struktur control sehingga perhatiannya difokuskan pada informasi domain [17]. Pengujian ini dilakukan untuk meminimalisir kesalahan dan memastikan keluaran yang dihasilkan sesuai dengan yang diinginkan. Bahasa pemrograman yang digunakan untuk membangun sistem ini adalah Microsoft Visual Basic 6.0 dan Microsoft Access untuk databasenya.

\section{Integrasi dan Uji Coba Sistem}

Program-program yang sudah lolos uji kemudian disatukan untuk menjalankan Sistem Pendataan Pasien pada Rekam Medis secara lengkap dengan mempergunakan data-data yang 
INTENSIF, Vol.3 No.2 August 2019

ISSN: 2580-409X (Print) / 2549-6824 (Online)

DOI: https://doi.org/10.29407/intensif.v3i2.12597

nyata di lapangan. Setelah uji coba sistem, kemudian sistem tersebut diberikan ke bagian bagian yang terkait.

5. Operasi dan Pemeliharaan

Setiap komputer pada bagian - bagian yang terkait terhubung dengan mempergunakan LAN ( Local Area Network) bertopologi bintang. Topologi ini menghubungkan semua komputer pada sentral atau konsentrator yang berupa perangkat hub atau switch [18]. Sistem kemudian dioperasikan dengan terlebih dahulu memberikan pelatihan kepada bagian - bagian yang terkait, dipantau dan diperbaiki bila masih ada kesalahan - kesalahan yang tidak terdeteksi di tahap pengujian sistem. Pemeliharaan terhadap sistem bisa dilakukan dengan membersihkan tabel dari data - data yang 'menggantung' akibat dari proses yang diinterupsi secara paksa.

Tahap pertama dan kedua pada metode Waterfall digambarkan oleh penulis dalam bentuk diagram-diagram yang terdapat pada UML ( Unified Modelling Language ). UML ( Unified Modelling Languange ) adalah suatu alat untuk memvisualisasikan hasil analisa dan desain yang berisi sintak dalam memodelkan sistem secara visual [19]. UML juga adalah bahasa pemodelan untuk sistem atau perangkat lunak berparadigma berorientasi objek. Abstraksi konsep dasar UML terdiri dari structural classification, dynamic behavior, dan model management dapat kita pahami main concepts sebagai term yang akan muncul pada saat membuat diagram dan view adalah kategori dari diagram tersebut. UML mendefinisikan diagram-diagram sebagai Use Case Diagram, Class Diagram, Statechart Diagram, Activity Diagram, Sequence Diagram, Collaboration Diagram, Component Diagram, dan Deployment Diagram[20].

\section{HASIL DAN PEMBAHASAN}

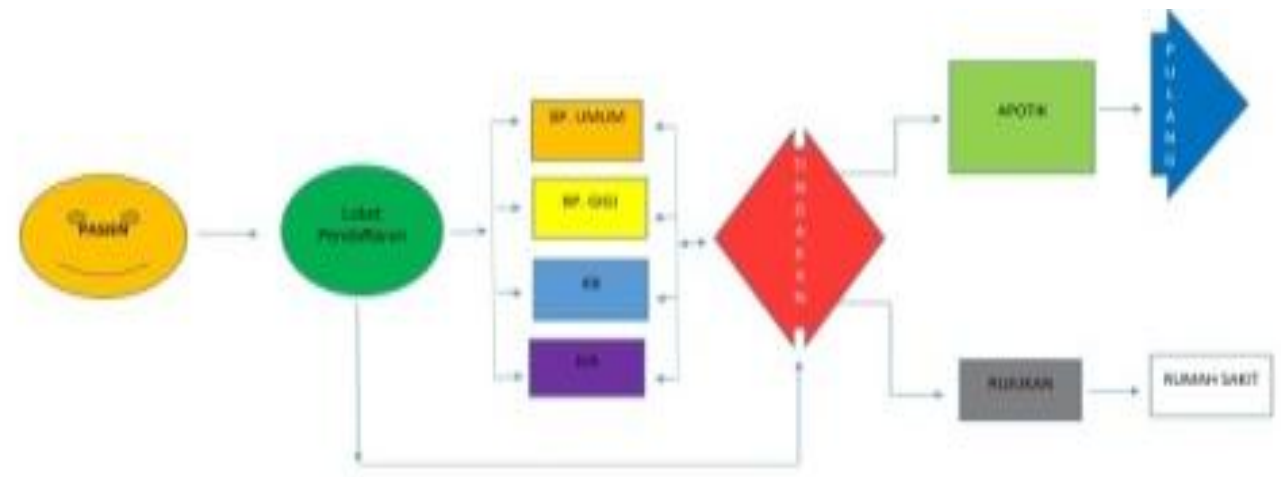

Gambar 5. AluR Pelayanan PUSKeSmas Pada ObyeK PENELITIAN

\section{Prosedur Sistem Berjalan}


Gambar 5 menunjukkan alur pelayanan puskesmas kecamatan matraman,kelurahan kayumanis secara keseluruhan. Untuk pasien baru: Pasien datang dan mendaftar dengan memberikan kartu identitas beserta kartu jaminan kesehatan kepada petugas loket, jika pasien memiliki, petugas loket kemudian akan bertanya kepada calon pasien tentang poli yang akan dituju. Petugas loket menuliskan tanggal kunjungan, nama,umur,jenis kelamin,alamat rumah yang tertera pada kartu identitas ke dalam Buku Besar untuk mendapatkan nomor registrasi beserta kartu kunjungan pasien. Pasien kemudian diberikan nomor antrian ke poli yang di tuju. Petugas loket memberikan kartu kunjungan pasien ke ruang rekam medis untuk dibuatkan buku rekam medis/status yg akan di berikan ke ruang poli. Setelah pasien baru selesai diperiksa, buku rekam medis/ status disimpan oleh bagian rekam medis dan kartu kunjungan pasien diserahkan ke pasien.

Alur Pasien lama: pasien mendaftar dengan memberikan kartu kunjungan pasien beserta kartu jaminan kesehatan kepada petugas loket, jika pasien memiliki. Petugas loket bertanya kepada pasien tentang poli yang dituju, lalu petugas loket menuliskan tanggal kunjungan,nama,umur,jenis kelamin,nomor registrasi ke Buku Besar. Kartu kunjungan pasien kemudain dibawa oleh bagian loket ke bagian rekam medis untuk dicarikan status /buku rekam medisnya. Pasien kemudian diberikan nomor antrian oleh bagian loket yang dibawa ke poli yang dituju. Prosedur sistem berjalan tersajikan pada gambar 6 di bawah ini dalam diagram aktifitas.

\section{Prosedur Sistem Usulan}

\section{Pendaftaran}

Alur Pendaftaran pasien baru, calon pasien yang datang akan melakukan pendaftaran dengan memberikan kartu identitas beserta kartu jaminan kesehatan kepada petugas loket, jika pasien memiliki. Petugas loket kemudian akan menginput data calon pasien baru dan mencetak kartu pasien. Petugas loket lalu menginput data pendaftaran pasien ( baru / lama ) sesuai dengan poli yang dituju, kemudian mencetak nomor antrian dari poli tersebut dan diberikan kepada pasien. 
INTENSIF, Vol.3 No.2 August 2019

ISSN: 2580-409X (Print) / 2549-6824 (Online)

DOI: https://doi.org/10.29407/intensif.v3i2.12597

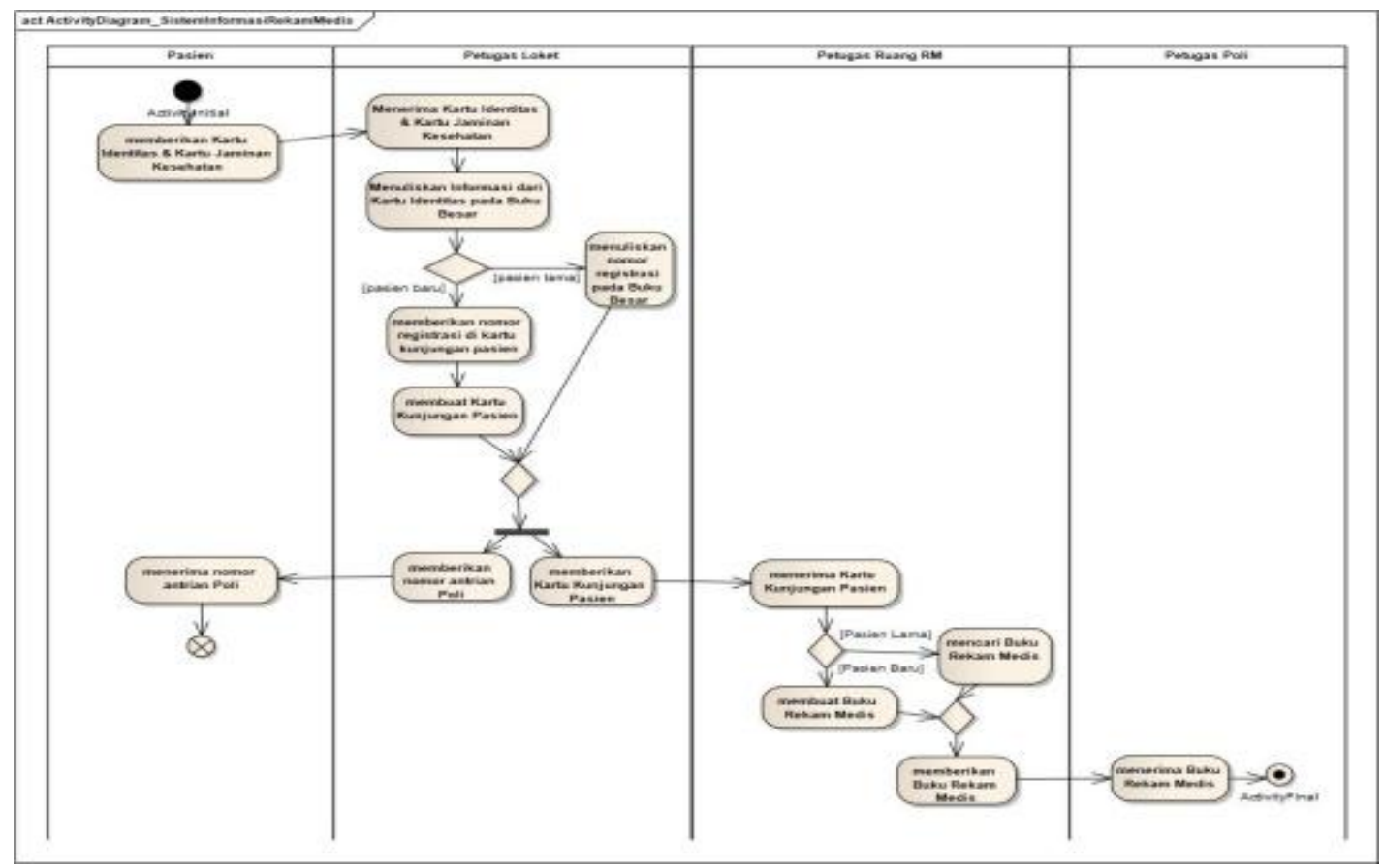

Gambar 6. ACTIVITY DIAGRAM SISTEM BERJALAN

\section{Pendataan Rekam Medis}

Pasien baru, petugas loket meminta pasien tersebut datang ke bagian Rekam Medis untuk dibukakan Data Rekam Medisnya. Untuk pasien lama, petugas loket meminta pasien tersebut langsung menuju ke bagian poliklinik yang dituju. Bagian Rekam Medis mempunyai tugas menginput, merubah, menghapus, melihat data poli, data dokter, data obat, data pegawai, data bagian, dan data tindakan,

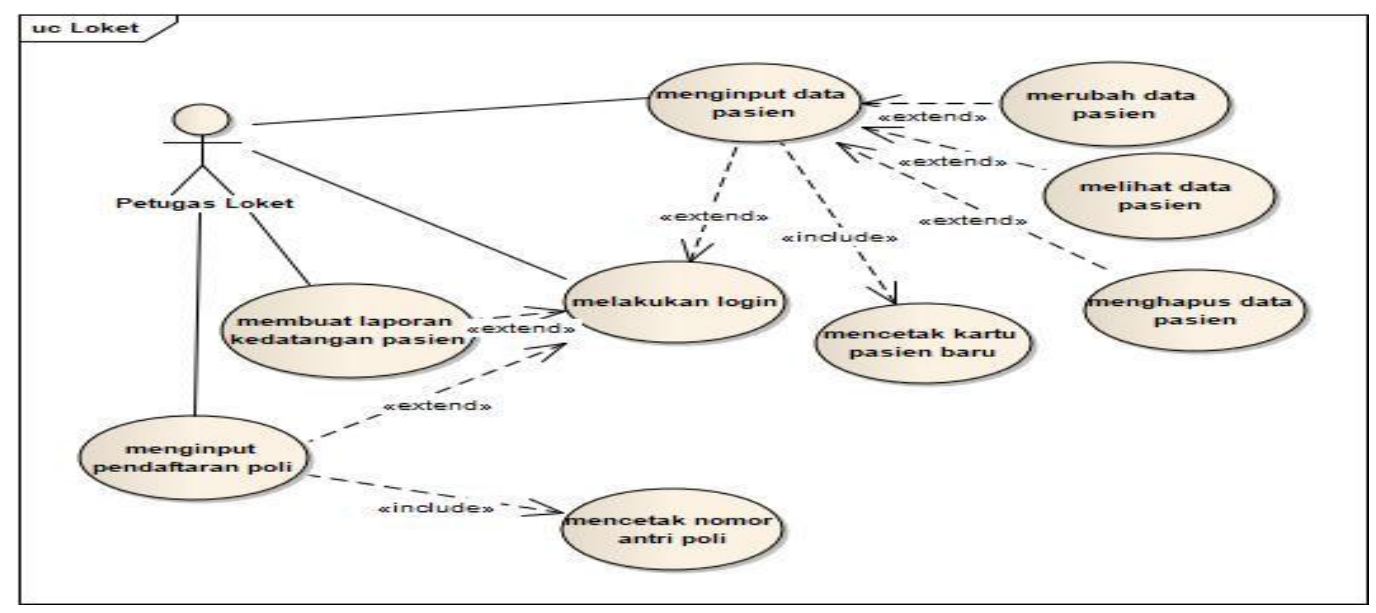

Gambar 7. USE CASE DIAGRAM FISH LEVEL BAGIAN LOKET PADA SISTEM USULAN

Gambar 7 dan gambar 8 menyajikan sistem usulan yang akan dibangun pada bagian loket dan bagian rekam medis. 


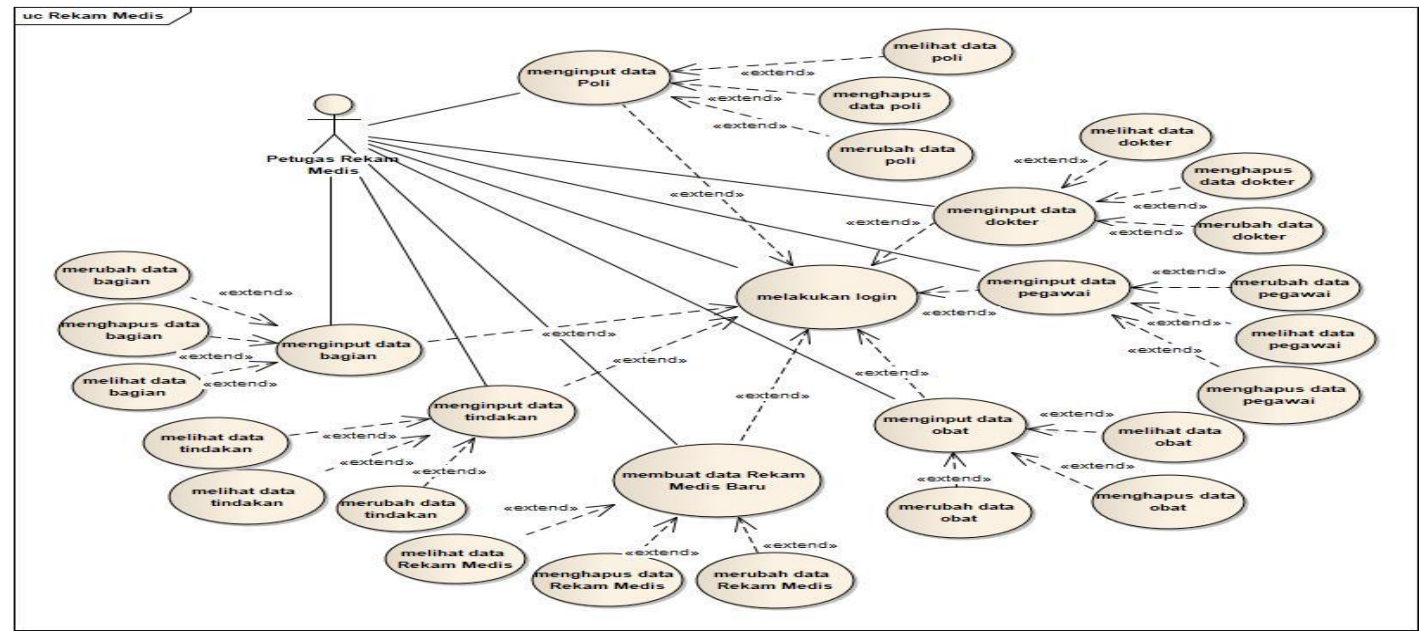

Gambar 8. USE CASE DIAGRAM FISH LEVEL BAGIAN REKAM MEDIS PADA SISTEM USULAN

\section{Pelayanan Poliklinik}

Pasien yang datang ke bagian poliklinik kemudian akan dipanggil oleh petugas poli sesuai dengan nomor antrian. Dokter kemudian akan melakukan pemeriksaan dan menginput uraian pemeriksaan dalam Data Pendaftaran Poli. Setelah pasien selesai diperiksa, pasien kemudian diminta oleh petugas poli ke bagian obat. Bagian poli kemudian menginput kode tindakan dan kode obat sesuai dengan uraian yang di input oleh dokter ke dalam Data Pendaftaran Poli. Bagian Poli juga akan membuat laporan per poliklinik ( dokter, pasien, kedatangan ) secara periode. Gambar 9 menyajikan fasilitas dari sistem usulan yang akan diberikan kepada petugas poliklinik dan dokter.

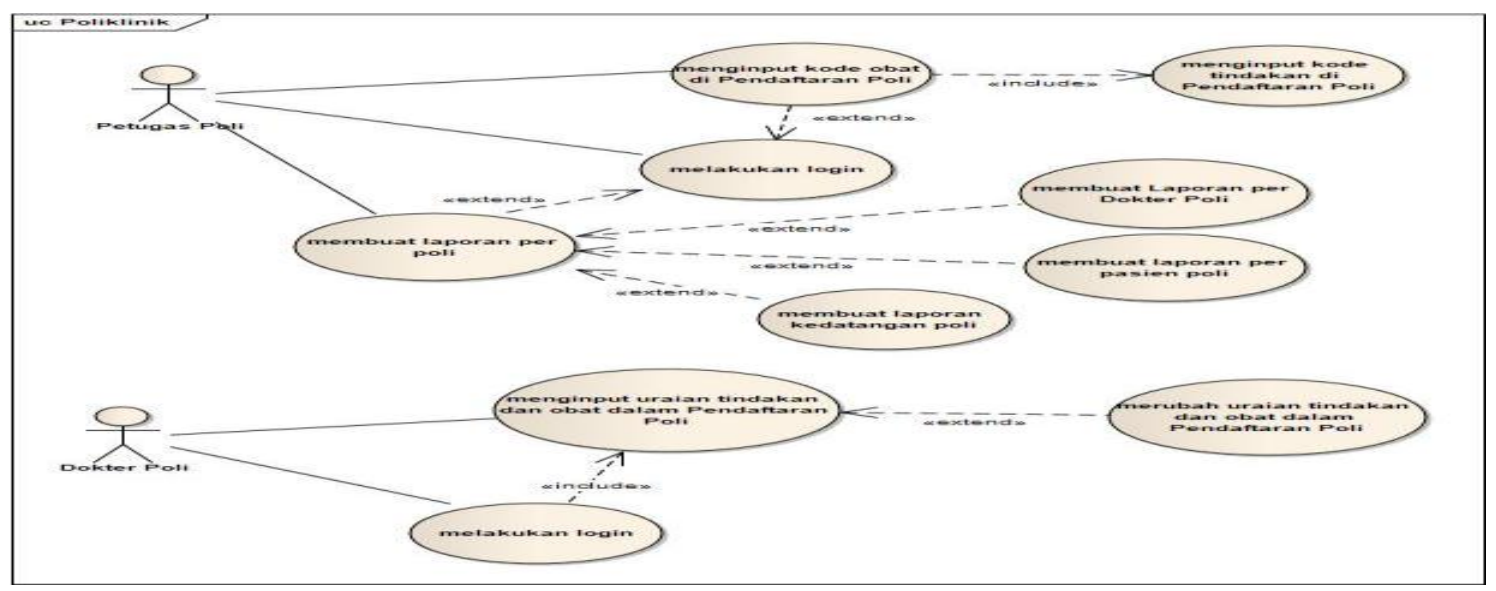

Gambar 9. USE CASE DIAGRAM FISH LEVEL B AGIAN POLIKLINIK 
INTENSIF, Vol.3 No.2 August 2019

ISSN: 2580-409X (Print) / 2549-6824 (Online)

DOI: https://doi.org/10.29407/intensif.v3i2.12597

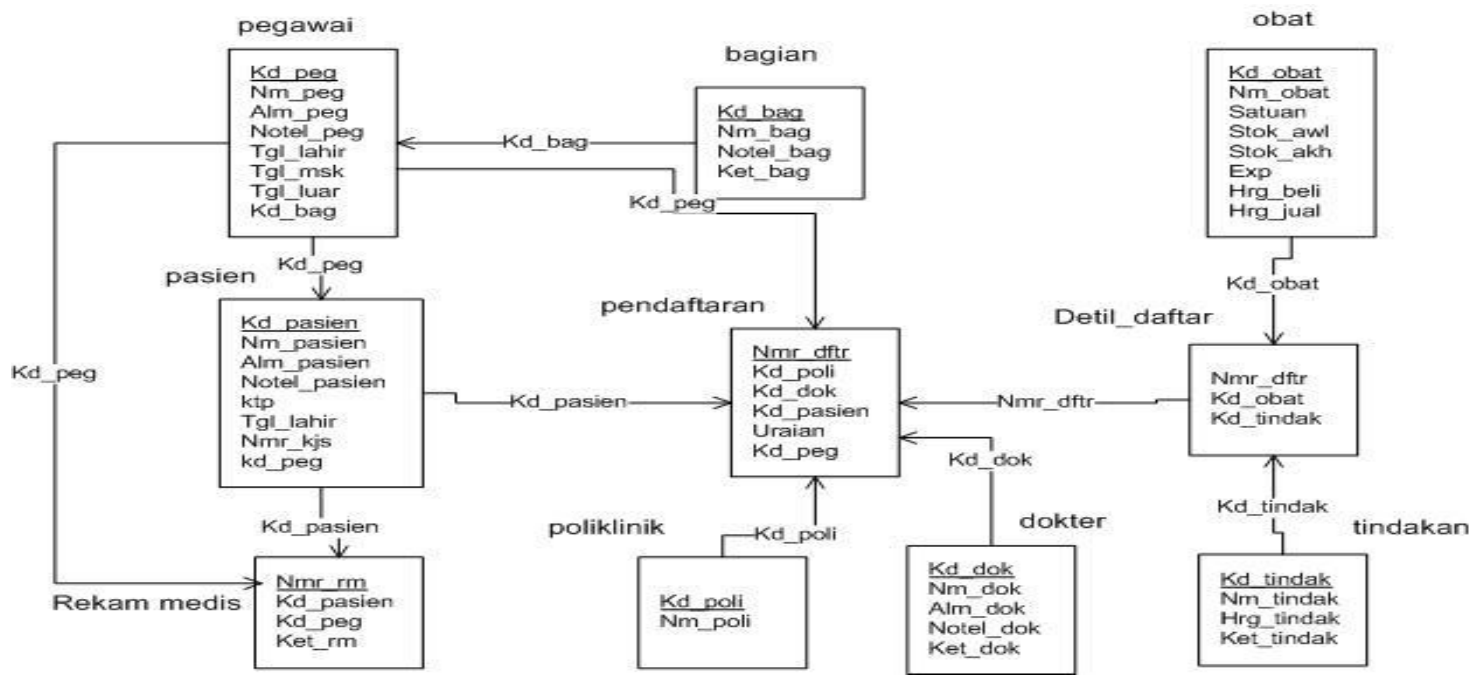

Gambar 10. LRS SISTEM INFORMASI REKAM MEDIS PUSKESMAS KECAMATAN MATRAMAN

Tampilan gambar 10 Merupakan desain Logical Relational Structure menguraikan proses pembentukan tabel sistem informasi.

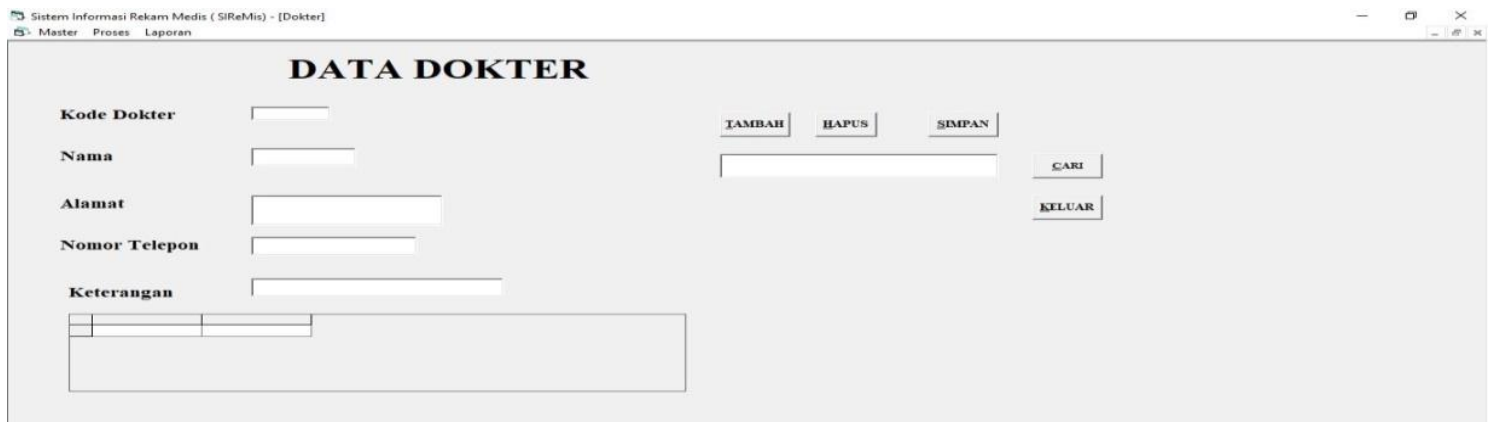

Gambar 11. FORM INPUT DATA DOKTER

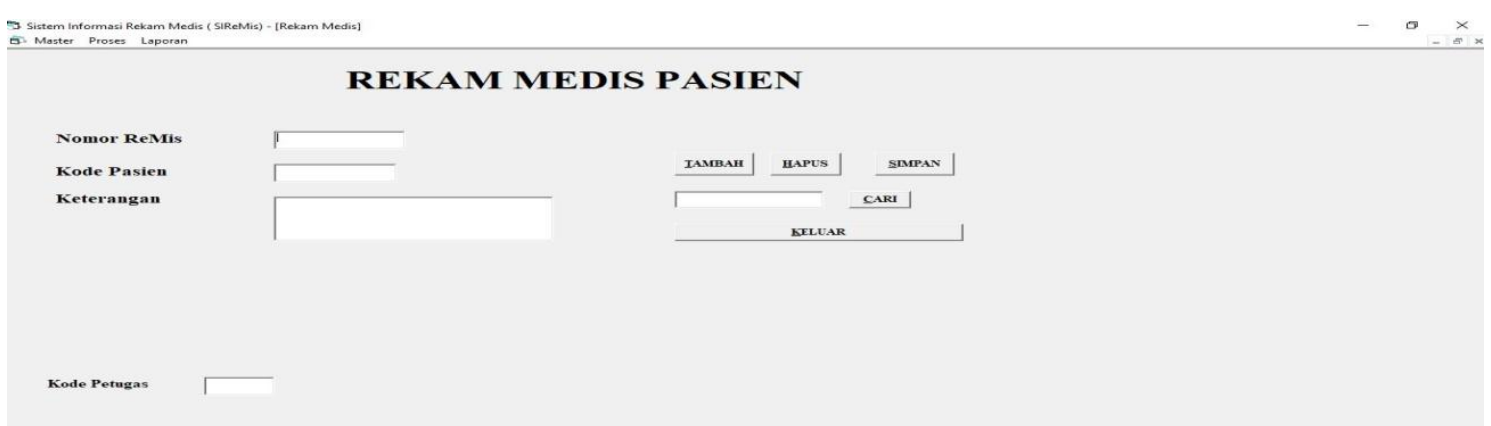

Gambar 12. FORM INPUT DATA PASIEN

Form Data Dokter pada gambar 11 dan Form Rekam Medis pada gambar 12merupakan form untama untuk menginputkan data yang akan dipergunakan pada SIReMis. Sedangkan pengujian Black-Box yang diterapkan pada Form Data Dokter dapat terlihat pada tabel 1 di bawah ini. Gambar 15 menggambarkan jaringan yang dipergunakan dalam SIReMis. 
TABEL 1. HASIL PENGUJIAN BLACK-BOX PADA FORM DATA DOKTER

\begin{tabular}{|c|c|c|c|c|}
\hline No. & $\begin{array}{l}\text { Skenario } \\
\text { pengujian }\end{array}$ & Test case & "Hasil yang diharapkan & $\begin{array}{c}\text { Hasil } \\
\text { pengujian }\end{array}$ \\
\hline 1. & $\begin{array}{l}\text { Klik tombol } \\
\text { tambah, masukkan } \\
\text { kode dokter yang } \\
\text { sudah ada }\end{array}$ & Kode Dokter : AY01 & $\begin{array}{l}\text { Sistem akan menolak } \\
\text { dan menampilkan "Kode } \\
\text { dokter sudah ada" }\end{array}$ & Valid \\
\hline 2. & $\begin{array}{l}\text { Klik tombol } \\
\text { tambah, masukkan } \\
\text { kode dokter yang } \\
\text { belum ada }\end{array}$ & Kode Dokter : AB12 & $\begin{array}{l}\text { Sistem akan menerima } \\
\text { dan kursor akan } \\
\text { berpindah ke kolom } \\
\text { nama }\end{array}$ & Valid \\
\hline 3. & $\begin{array}{l}\text { Klik tombol } \\
\text { tambah, salah satu } \\
\text { MBARkolom tidak } \\
\text { di isi, klik tombol } \\
\text { simpan }\end{array}$ & $\begin{array}{l}\text { Kode Dokter : AB12 } \\
\text { Nama : Bambang } \\
\text { Alamat : Bogor } \\
\text { Nomor Telepon : } 12345 \\
\text { Keterangan : ( kosong ) }\end{array}$ & $\begin{array}{l}\text { Sistem akan menolak } \\
\text { dan menampilkan "Data } \\
\text { belum lengkap" }\end{array}$ & Valid \\
\hline 4. & $\begin{array}{l}\text { Klik tombol } \\
\text { tambah, seluruh } \\
\text { kolom terisi, klik } \\
\text { tombol simpan }\end{array}$ & $\begin{array}{l}\text { Kode Dokter : AB12 } \\
\text { Nama : Bambang } \\
\text { Alamat }: \text { Bogor } \\
\text { Nomor Telepon : } 12345 \\
\text { Keterangan : Shift Sore }\end{array}$ & $\begin{array}{l}\text { Sistem akan menerima } \\
\text { dan menampilkan "Data } \\
\text { sudah tersimpan" }\end{array}$ & Valid \\
\hline
\end{tabular}

\section{KESIMPULAN DAN SARAN}

Sistem Informasi Rekam Medis di Puskesmas Kecamatan Matraman Jakarta dapat membantu petugas-petugas yang betugas di bagian loket, bagian poliklinik, dokter, dan khususnya bagian rekam medis dalam mendata dan melakukan pencarian data rekam medis untuk pasien, hal itu ditunjukkan berdasarkan hasil pengujian yang dilakukan dengan metode black-bok dengan hasil yang sesuai desai usecase yang dibuat.. Sistem ini juga menghemat tempat penyimpanan data pasien yang terdapat dalam rekam medis. Pelatihan akan diberikan kepada para pengguna 'Sistem Informasi Rekam Medis' di masing - masing bagian yang memerlukan. Saran untuk Sistem Rekam Medis ini agar dikemudian hari dapat dikembangkan sehingga terintegrasi dengan bagian apotik dan bagian pembayaran terkait Kartu Jaminan Kesehatan yang dimiliki oleh pasien.

\section{DAFTAR PUSTAKA}

[1] Karman, A. Sakka, and S. Saptaputra, "Faktor-Faktor Yang Berhubungan Dengan Pemanfaatan Pelayanan Kesehatan Bagi Masyarakat Pesisir Di Desa Bungin Permai Kecamatan Tinanggea Kabupaten Konawe Selatan," J. Ilm. Mhs. Kesehat. Masy., vol. 1, no. 3, pp. 1-9, 2016.

[2] B. Eninurkhayatun, A. Suryoputro, and E. Y. Fatmasari, "Analisis Tingkat Kepuasan Pasien Terhadap Kualitas Pelayanan Rawat Jalan di Puskesmas Duren dan Puskesmas 
INTENSIF, Vol.3 No.2 August 2019

ISSN: 2580-409X (Print) / 2549-6824 (Online)

DOI: https://doi.org/10.29407/intensif.v3i2.12597

Bergas Kabupaten Semarang Tahun 2017,” J. Kesehat. Masy., vol. 5, pp. 33-42, 2017.

[3] A. N. Renny and P. Beni, "Sistem Informasi Rekam Medis," J. Manaj. Sist. Inform., vol. 1, no. 2, pp. 147-158, 2016.

[4] N. Hardinata, "Analisis Dan Perancangan Sistem Informasi Rekam Medis Pada Puskesmas Kecamatan X,” Teknol. Inf., vol. 1, no. 1, pp. 6-8, 2015.

[5] R. Nugraheni, "Analisis Pelayanan Rekam Medis Di Rumah Sakit X Kediri Jawa Timur Analysis Services Medical Record in Bhayangkara Hospitals Kediri-East Java,” J. Wiyata, vol. 2, pp. 169-175, 2015.

[6] D. H. Kusuma, M. N. Shodiq, D. Yusuf, and L. Saadah, "Si-Bidan: Sistem Informasi Kesehatan Ibu dan Anak," INTENSIF J. Ilm. Penelit. dan Penerapan Teknol. Sist. Inf., vol. 3, no. 1, p. 43, Feb. 2019.

[7] F. Giyana, P. Administrasi, and K. Kesehatan, "Analisis Sistem Pengelolaan Rekam Medis Rawat Inap Rumah Sakit Umum Daerah Kota Semarang," JurnalKesehatan Masy., vol. 1, no. 2, pp. 48-61, 2012.

[8] P. D. Abda'u, W. W. Winarno, and H. Henderi, "Evaluasi Penerapan SIMRS Menggunakan Metode HOT-Fit di RSUD dr. Soedirman Kebumen,” INTENSIF J. Ilm. Penelit. dan Penerapan Teknol. Sist. Inf., vol. 2, no. 1, p. 46, Feb. 2018.

[9] G. W. Sasmito, "Penerapan Metode Waterfall Pada Desain Sistem Informasi Geografis Industri Kabupaten Tegal,” J. Pengemb. IT, vol. 2, no. 1, pp. 6-12, 2017.

[10] A. S. T. Sofan Tohir, K. Kusrini, and S. Sudarmawan, "Implementasi Pengembangan Sistem Model Water Fall Untuk Data Warehouse Akademik,” INTENSIF, vol. 1, no. 2, p. 108, Aug. 2017.

[11] I. Nugroho, H. Listiyono, and S. N. Anwar, "Peramcangan Unified Modelling Language Aplikasi Sarana Prasarana Pendukung Pariwisata Kota Semarang," Proceeding SENDI, vol. 2, no. 1, pp. 90-95, 2017.

[12] W. H. Utomo, Pemrograman Basis Data Berorientasi Objek, 1st ed. Yogyakarta: C.V ANDI OFFSET, 2010.

[13] I. Akil, "Rekayasa Perangkat Lunak Dengan Model Unified Process Studi Kasus: Sistem Informasi Journal," J. Pilar Nusa Mandiri, vol. 7, no. Maret, p. 11, 2016.

[14] M. D. Cahyono, K. I. Satoto, and R. Kridalukmana, "Sistem Informasi Manajemen Pemesanan Dan Penjualan Pada UNDIP Distro. Jurnal Teknologi dan Sistem Komputer, Vol.3, No.3, Agustus 2015 (e-ISSN: 2338-0403),” J. Teknol. dan Sist. Komput., vol. 3, no. 3, pp. 370-378, 2016.

[15] A. Sukamaindrayana and Rahman Sidik, "Aplikasi grosis Toko RSIDIK BUNGUSARI Tasikmalaya," J. Manaj. Inform., vol. 4, no. 2, 2017. 
[16] I. Sumirat, "jumantaka - jurnal elektronik stmik dci.pdf," vol. 01, no. 01, pp. 1-6, 2017.

[17] T. S. Jaya, "Pengujian Aplikasi dengan Metode Blackbox Testing Boundary Value Analysis (Studi Kasus: Kantor Digital Politeknik Negeri Lampung)," J. Inform. J. Pengemb. IT, vol. 03, no. 02, pp. 45-46, 2018.

[18] S. N. Khasanah, "Keamanan Jaringan Dengan Packet Filtering Firewall (Studi Kasus: PT.Sukses Berkat Mandiri Jakarta)," J. Khatulistiwa Inform., vol. IV, no. 2, p. 2016, 2016.

[19] P. Bergerak et al., "Summary for Policymakers," J. Media Infotama, vol. 9, no. 2, pp. 16, 2013.

[20] A. Nugroho, Rekayasa Perangkat Lunak Berorientasi Objek dengan Metode USDP ( Unified Sostware Development Process ). Yogyakarta: Penerbit ANDI, 2010. 